\title{
Effects of Honey Sales Performed via Television Commercials on Consumers' Buying Behavior
}

\author{
Dilek Kabakcı ${ }^{1, a, *}$, Soner Çankayaa ${ }^{2, b}$, Gökhan Akdeniz ${ }^{3, c}$, Engin Derebaşı ${ }^{4, d}$ \\ ${ }^{1}$ Department of Animal Production and Technologies, Faculty of Applied Sciences, Muş Alparslan University, 49250 Muş, Turkey \\ ${ }^{2}$ Yaşar Doğu Sport Science Fakulty, Ondokuz Mayıs University, 55139 Samsun, Turkey \\ ${ }^{3}$ Apiculture Research Institute, 52100 Ordu, Turkey \\ ${ }^{4}$ Perşembe Directorate of Provincial Agriculture and Forestry, 52750 Ordu, Turkey
}

*Corresponding author

\begin{tabular}{l|l}
\hline A R T I L E IN F O \\
\hline Research Article
\end{tabular}

A B S T R A C T

Honey is the most known and consumed bee product by consumers. Therefore, from the past to the present, the investigation of the factors affecting the supply and consumption of honey has been on the agenda of the researchers. For this purpose, in our survey study, the effects of honey sales carried

Received : 08/01/2020

Accepted : 16/10/2020 out via television channels (commercials) on consumers were investigated. According to the survey results, it was determined that $87.91 \%$ of consumers had a negative view about honey sales performed via television, $3.54 \%$ had a positive opinion, and $8.55 \%$ had no opinion on the issue. It was found that $5.83 \%$ of consumers bought honey through television commercials, and the education, income, gender and number of individuals in their households have an effect on the tendency to buy honey. Regarding the exposing of companies selling fake or adulterated honey by the Ministry of Agriculture

Keywords: and Forestry, results showed that this situation positively affected 54.53 of consumers in terms of trust in honey positively, affected $13.30 \%$ of consumers negatively, and did not affect $13.30 \%$ of Honey

Consumption Awareness Honey Purchasing Behavior Adulterated Honey consumers in any way. As a result, deceptive honey commercials lead to consumer abuse and create an environment of distrust of honey. In order to minimize speculation on honey, it is seen necessary to increase deterrent penalties for businesses that lead to unfair competition.

Media

Türk Tarım - Gıda Bilim ve Teknoloji Dergisi, 8(11): 2330-2333, 2020

\section{Televizyon Reklamları İle Gerçekleştirilen Bal Satışlarının Tüketicilerin Satın Alma Davranışları Üzerine Etkileri}

\begin{tabular}{|c|c|}
\hline M A K A L E B İ L G İ S İ & Ö Z \\
\hline $\begin{array}{l}\text { Anahtar Kelimeler: } \\
\text { Bal } \\
\text { Tüketim bilinci } \\
\text { Bal satın alma davranışı } \\
\text { Tağşişli bal } \\
\text { Medya }\end{array}$ & 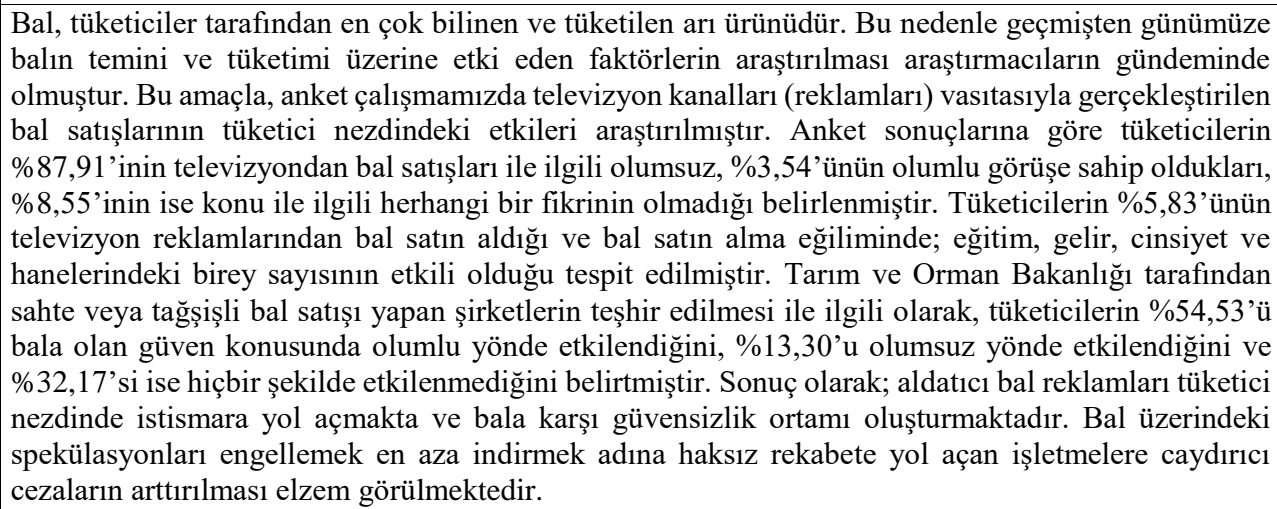 \\
\hline
\end{tabular}




\section{Introduction}

As a result of beekeeping studies which is one of the oldest agricultural activities of the World in the historical process, many bee products such as honey, royal jelly, propolis and bee venom are obtained (Kumova and Korkmaz 2000). These products are widely used both as a foodstuff and in the treatment of many diseases (Bölüktepe and Y1lmaz, 2006; Kaftanoglu, 2003). On the other hand, consumption is the use of goods and services to compansate the needs of human. In other words it is defined as acquisition, ownership or use of a good or service to satisfy a particular need. Depending on the progress and developments required by modern life, economic growth, technological developments, changing cultural and social factors lead to major changes in the existing consumption patterns in the society. At the same time, these changes and developments required consumers to be more knowledgeable and more researcher in the consumption process. This active behavior of consumers in the consumption process provides that the market is constantly dynamic, lively and competitive (Savaş, 2015). Consumer behavior is a process that belongs to decisions of consumers regarding which goods and services will be purchased as well as where, how, where, when and whether to purchase them. There are many factors that affect consumer behavior. The subject of consumer behavior which is an interdisciplinary approach, is the scene of the common work of scientists on various subjects. In order to prepare a healthy future for the goods, prices, promotions and distribution activities that we call marketing components, the marketing manager has to know the market and the consumers in this market and develop the suitable marketing component before making decisions about them. Understanding the reasons why consumer prefers one good to another requires understanding the mechanism that drives him to purchase it (Penpece, 2006). In this study, it was aimed to research behaviours of consumer regarding Turkish people from different regions purchasing honey from television and Ministry's exposing of firms that make adulterated production.

\section{Material and Method}

The data that was gathered by face to face interviews with randomly selected households forms the material of study. In order to determine the sample volume that represents the main mass, three stage cluster sampling and systematic sampling methods were used. In the study primarily provinces that represent seven region of Turkey were determined by considering population number. According to this İstanbul, Bursa, İzmir, Manisa, Ankara,
Konya, Van, Erzurum, Gaziantep, Şanlıurfa, Adana, Antalya, Samsun and Trabzon were chosen. In addition, primarily normality test and variance homogeneity test were applied to the continuous data obtained in the study. Angle transformation was applied to the percentages obtained at the end of the study. In the research in order to reveal if situations such as honey sales, purchasing honey from television and so on. change according to the regions Chi-square analysis was used wheras in order to determine the factors effective on consumers' purchasing from television, multiple regression analysis was used. All statistical calculations were made in SPSS $20.0 \mathrm{~V}$ statistical package program. The findings of the study were given as $\mathrm{n}, \%$ and accepted as significant at $\mathrm{P}<0.05$ was accepted as significant at significance level.

\section{Findings and Discussion}

Television has a great impact on community life as good or bad. As a means of social communication, all kinds of broadcasts on television affect people. In addition, television advertising used in marketing a product significantly affects the purchasing behavior of individuals. In this study, the opinions of consumers who participated in the survey about the sale of honey from television was given in Table 1.

It was obtained that $87.91 \%$ of consumers had negative opinion about honey sales from television whereas $3.54 \%$ had positive opinion and $8.55 \%$ had no idea about the subject (Table 1). In the research, it was also found out that the effect of television on the honey purchasing behavior of consumers was important $\left(\chi^{2}: 164,1 ; \mathrm{P}<0,001\right)$. As the results of our study was found compatible with Tunca et al (2015) and Sayılı (2013) whereas Onurlubaş (2015), Çiğdem, (2017); Abdallqadir, (2018); Ay, (2019); Sarıalp, (2019); Mohamed, (2019); Bülbül, (2019) reported that social media (internet, facebook, youtube) affects consumer behavior rather than television.

Situation of consumers purchasing honey from television was given in Table 2.

The effect of the Ministry of Agriculture and Forestry on consumers about exposure of companies selling fake or adulterated honey, was given in Table 1.5. 54.53\% of the consumers stated that they were positively affected by the trust in honey, $13.30 \%$ were negatively affected and $32.17 \%$ were not affected in any way. It was determined that the Ministry's exposure to the companies that make fake honey $(\chi 2: 29.9 ; \mathrm{P}<0.001)$ creates a difference in the effect level created on consumers according to regions.

Table 1. Opinions of consumers on honey sales from television

\begin{tabular}{l|rccccr}
\multirow{2}{*}{\multicolumn{1}{c}{ Regions }} & \multicolumn{2}{c}{ Positive } & \multicolumn{2}{c}{ Negative } & \multicolumn{2}{c}{ No İdea } \\
\cline { 2 - 6 } & $\mathrm{n}$ & \multicolumn{1}{c}{$\mathrm{n}$} & $\mathrm{n}$ & $\%$ & $\mathrm{n}$ & \multicolumn{1}{c}{$\%$} \\
\hline Marmara & 13 & 2.93 & 389 & 87.61 & 42 & 9.46 \\
Aegean & 5 & 2.75 & 167 & 91.76 & 10 & 5.49 \\
Central Anatolia & 5 & 1.62 & 276 & 89.32 & 28 & 9.06 \\
East Anatolia & 10 & 4.44 & 197 & 87.56 & 18 & 8.00 \\
Southeastern Anatolia & 13 & 7.30 & 143 & 80.34 & 22 & 12.36 \\
Mediterranean & 3 & 1.00 & 285 & 95.00 & 12 & 4.00 \\
Black Sea & 7 & 4.73 & 124 & 83.78 & 17 & 11.49 \\
\hline Total & 56 & 3.54 & 1.581 & 87.91 & 149 & 8.55 \\
\hline
\end{tabular}


Table 2. The situation of consumers purchasing honey from television

\begin{tabular}{l|rllc}
\hline \multirow{2}{*}{ Regions } & \multicolumn{3}{c}{ Yes } & \multicolumn{2}{c}{ No } \\
\cline { 2 - 5 } & $\mathrm{n}$ & $\%$ & $\mathrm{n}$ & $\%$ \\
\hline Marmara & 14 & 3.15 & 172 & 96.85 \\
Aegean & 8 & 4.44 & 301 & 95.56 \\
Central Anatolia & 7 & 2.27 & 199 & 91.73 \\
East Anatolia & 18 & 8.29 & 175 & 92.59 \\
Southeastern Anatolia & 14 & 7.41 & 279 & 93.94 \\
Mediterranean & 18 & 6.06 & 129 & 90.85 \\
Black Sea & 13 & 9.15 & 1.685 & 94.17 \\
\hline Total & 92 & 5.83 & & \\
\hline
\end{tabular}

Table 3. The effect of honey sold on television on the purchasing behavior of consumers

\begin{tabular}{l|rlrrrc}
\hline \multirow{2}{*}{ Regions } & \multicolumn{2}{c}{ Positive } & \multicolumn{2}{c}{ Negative } & \multicolumn{2}{c}{ Does not effect } \\
\cline { 2 - 7 } & $\mathrm{n}$ & $\%$ & $\mathrm{n}$ & $\%$ & $\mathrm{n}$ & $\%$ \\
\hline Marmara & 10 & 2.28 & 89 & 20.27 & 340 & 77.45 \\
Aegean & 3 & 1.65 & 18 & 9.89 & 161 & 88.46 \\
Central Anatolia & 2 & 0.65 & 129 & 42.16 & 175 & 57.19 \\
East Anatolia & 133 & 5.80 & 48 & 21.43 & 163 & 72.77 \\
Southeastern Anatolia & 13 & 7.30 & 75 & 42.13 & 90 & 50.56 \\
Mediterranean & 4 & 1.36 & 122 & 41.50 & 168 & 57.14 \\
Black Sea & 8 & 5.59 & 21 & 14.69 & 114 & 79.72 \\
\hline Total & 53 & 3.52 & 502 & 27.44 & 1.211 & 69.04 \\
\hline
\end{tabular}

Education $(\mathrm{P}<0.05)$, income $(\mathrm{P}<0.10)$, gender $(\mathrm{P}<0.10)$ and the number of individuals in their households $(\mathrm{P}<0.001)$ were effective variables in the tendency of consumers in purchasing honey from television.

Table 4. Variables in consumers' purchasing honey from television

\begin{tabular}{|c|c|c|c|c|c|c|c|}
\hline & \multicolumn{2}{|c|}{ Collinearity Statictics } & \multicolumn{5}{|c|}{ Variables in the Equation } \\
\hline & Tolerance & VIF & $\mathrm{B}$ & S.E. & Wald & df & Sig. \\
\hline \multicolumn{8}{|l|}{ Step $1^{\mathrm{a}}$} \\
\hline Age & 0.912 & 10.097 & 0.000 & 0.011 & 0.001 & 1 & 0.972 \\
\hline Education & 0.737 & 1.356 & 0.230 & 0.097 & 5.607 & 1 & 0.018 \\
\hline Income & 0.792 & 1.263 & 0.000 & 0.000 & 3.238 & 1 & 0.072 \\
\hline $\mathrm{N}$ of indv. & 0.959 & 1.043 & -0.486 & 0.097 & 25.071 & 1 & $<0.001$ \\
\hline Occupation & 0.938 & 1.066 & 0.065 & 0.054 & 1.433 & 1 & 0.231 \\
\hline Region & 0.972 & 1.029 & 0.044 & 0.052 & 0.717 & 1 & 0.397 \\
\hline Gender & 0.902 & 1.109 & 0.612 & 0.339 & 3.263 & 1 & 0.071 \\
\hline
\end{tabular}

${ }^{\mathrm{a}}$ Variable(s) entered on step 1: age, education, income, nmber of individuals, occupation, region, gender.

Table 5. The effects of the Ministry of Agriculture and Forestry on consumers about exposure of companies selling fake or adulterated honey

\begin{tabular}{l|rrrrrr}
\hline \multirow{2}{*}{ Regions } & \multicolumn{2}{c}{ Positive } & \multicolumn{2}{c}{ Negative } & \multicolumn{2}{c}{ Does not effect } \\
\cline { 2 - 7 } & $\mathrm{n}$ & $\%$ & $\mathrm{n}$ & $\%$ & $\mathrm{n}$ & $\%$ \\
\hline Marmara & 247 & 56.01 & 66 & 14.97 & 128 & 29.02 \\
Aegean & 117 & 64.29 & 8 & 4.40 & 57 & 31.32 \\
Central Anatolia & 132 & 43.14 & 69 & 22.55 & 105 & 34.31 \\
East Anatolia & 110 & 49.11 & 6 & 2.68 & 108 & 48.21 \\
Southeastern Anatolia & 79 & 45.14 & 54 & 30.68 & 42 & 24.00 \\
Mediterranean & 133 & 45.70 & 31 & 10.65 & 127 & 43.64 \\
Black Sea & 112 & 78.32 & 10 & 6.99 & 21 & 14.69 \\
\hline Total & 930 & 54.53 & 244 & 13.30 & 588 & 32.17 \\
\hline
\end{tabular}

\section{Result}

It was stated that $78.32 \%$ of the consumers in the Black Sea Region were positively, $30.68 \%$ of the consumers in the South East Anatolia Region were negatively affected whereas $48.21 \%$ of the consumers in the East Anatolia Region were neither positively nor negatively affected. As our study was found compatible with Gürer and Akyol (2018), it was found incompatible with the study of Sayıl1 (2013).
According to the results of the research, it was obtained that $87.91 \%$ of consumers have negative opinion about honey sales from television, $3.54 \%$ have positive opinion and $8.55 \%$ have no idea about the subject. $94.17 \%$ of the consumers stated that they did not purchase honey from television and $5.83 \%$ stated that they bought. $69.04 \%$ of the consumers stated that the honey sold on television did not affect their purchasing behavior whereas $27.44 \%$ of them 
were negatively affected and $3.52 \%$ were positively affected.

It was obtained that $54.53 \%$ of consumers were positively affected by their trust in honey, $13.30 \%$ were negatively affected and $32.17 \%$ were not affected in any way as a result of exposure of companies selling fake or adulterated honey by the Ministry of Agriculture and Forestry. According to the statistical test results, it was also determined that the variables of purchasing honey from television, living region, television and the ministry exposing adulteration companies were statistically significant $(\mathrm{P}<0.001)$ in purchasing behaviour of consumers. As a result of study, it was found out that the sale of honey from television and the behavior of purchasing honey from television vary according to the regions.

\section{Acknowledgement}

This article is based on the findings of research, which was finacially supported by TAGEM, with the proje number of TAGEM/TEAD/14/A-15/P-02/003.

\section{References}

Abdallqadır EA. 2018. Medya ve Medyanın Tüketicinin Satın Alma Davranışı Üzerine Etkisi: Süleymaniye' de Bir Alan Araştırması. Bingöl Üniversitesi Sosyal Bilimler Enstitüsü Yüksek Lisans Tezi. Bingöl.

Ay E. 2019. Sosyal medya pazarlamasının Satın alma davranışı ve Marka Sadakatine Etkisi Üzerine Bir Uygulama. Galatasaray Üniversitesi Sosyal Bilimler Enstitüsü Yüksek Lisans Tezi. İstanbul.

Bölüktepe FE, Yılmaz S. 2006. Tüketicilerin Bal satın Alma Davranış ve Alışkanlıklarını Etkileme Sürecinde Markanın Önemini Belirlemeye yönelik Bir Araştırma Uludağ Arıcılık Dergisi. Say.135-142. Bursa.

Bülbül RB. 2019. Sosyal Medyanın Satın Alma Davranışına Etkisi Ankara İlinde Bir Uygulama. Ufuk Üniversitesi Sosyal Bilimler Enstitüsü Yüksek Lisans Tezi. Ankara.

Çiğdem MB. 2017. Medıa Psychology Effects On Consumer Buyıng Behavır. Bahçeşehir Üniversitesi Pazarlama Yüksek Lisans Tezi. İstanbul.
Gürer B, Akyol E. 2018. Tüketicilerin Bal Tüketiminde Gıda Güvenirliği Bilincinin İncelenmesi: Niğde İli Örneği. Türk Tarım - Gida Bilim ve Teknoloji Dergisi 6 (10): 1303 - 1310. Kaftanoğlu O. 2003. Ekolojik ve Organik Arı Ürünleri Üretimi. 2. Marmara Arıcılık Kongresi Bildiri Kitabı. Yalova.

Kumova U, Korkmaz A. 2000. Arı Ürünleri Tüketim Davranışları Üzerine Bir Araştırma, Türkiyede Arıcılık Sorunları ve 1.Ulusal Arıcılık Sempozyumu 28-30 Eylül 1999. Sayfa 29141, Kemaliye/Erzincan.

Mohamed R. 2019. Sosyal Medyada Pazarlama Aktivitelerinin Tüketici Tarafindan Algılanmasının Marka ve Satın Alma Davranış1 Üzerine Etkisi. Akdeniz Üniversitesi Sosyal Bilimler Enstitüsü Yüksek Lisans Tezi. Antalya

Onurlubaş E. 2015. Tüketicilerin Gida Güvenliği Konusunda Bilinç Düzeylerinin Ölçülmesi: Tokat İli Örneği. Gaziosmanpaşa Üniversitesi Fen Bilimleri Enstitüsü Doktora Tezi. Tokat.

Penpece D. 2006. Yüksek Lisans Tezi. Tüketici davranışlarını belirleyen etmenler: Kültürün Tüketici davranışları üzerindeki etkisi. Kahramanmaraş Sütçü İmam Üniversitesi Sosyal Bilimler Enstitüsü İşletme ABD. sayfa 155.Kahramanmaraş

Saner G, Yücel B, Yercan M, Karaturhan B, Engindeniz S, Çukur F, Kösoğlu M. 2011. Organik ve konvansiyonel Bal üretiminin teknik ve ekonomik yönden geliştirilmesi ve alternatif pazar olanaklarının saptanması Üzerine bir araştırma: İzmir ili kemalpaşa ilçesi örneği. Tarımsal Ekonomi ve Politika Geliştirme Enstitüsü. Tepge Yayın No: 195 Isbn: 978-975-407-333-1 Proje Sonuç Raporu. Ankara.

Sarıalp S. 2019. Sağlık Sektöründe, Tüketici Satın Alma Davranışında Sosyal Medya Reklamlarının Etik Boyutu. Atılım Üniversitesi Sosyal Bilimler Enstitüsü Yüksek Lisans Tezi. Ankara.

Savaş B. 2015. Yüksek Lisans Tezi. Tüketici-Tüketici Etkileşiminin Tüketici Satın Alma Kararları Ve Memnuniyet Düzeylerine Etkisi. Kastamonu İli Örneği. Karabük Üniversitesi Sosyal Bilimler Enstitüsü İktisat ABD. Sayfa 142. Kastamonu.

Sayılı M. 2013. Tokat İlinde Tüketicilerin Arı Ürünleri Tüketim Durumları ve Alışkanlıkları. Uludağ Arıcılık Dergisi, 13 (1): 16-22, Bursa.

Tunca İvgin R, Taşkın A, Karadavut U. 2015. Türkiye' de Bazı İllerdeki Tüketim Alışkanlıklarının ve Farkındalık Düzeylerinin Belirlenmesi. Türk Tarım - Gıda Bilim ve Teknoloji Dergisi. 3(7). Sayfa556-561. 